\title{
Mycelial growth of the edible wild mushrooms Floccularia luteovirens in different culture mediums and pH
}

\section{Arana-Gabriel, Yolanda; Burrola-Aguilar, Cristina*; Alcalá-Adán, Alejandro; Zepeda-Gómez, Carmen; Estrada Zúñiga, María Elena}

Universidad Autónoma del Estado de México. Campus El Cerrillo Piedras Blancas, Toluca. Estado de México. México. CP. 50200.

*Corresponding author: cba@uaemex.mx

\begin{abstract}
Objectives: To evaluate mycelial growth and biomass production of $F$. luteovirens in different culture mediums and $\mathrm{pH}$ values.

Design/methods/approach: The study was carried out in two stages. In the first stage, the amount of biomass produced and growth rate was measured in five generalist culture mediums. During the second stage, the pH was adjusted to 4, 5, and 6 in three of the five mediums, in order to increase biomass and growth speed shown in the first stage.

Results: $\mathrm{pH}$ is an influential factor in the availability of nutrients needed by the fungus, which is shown by the increase or inhibition of mycelial growth and biomass production. During the first stage, coconut and malt extract agar were the most favorable for mycelial development, while corn meal agar was the least favorable. When the pH was modified, malt extract agar with a pH of 4 was the most efficient in terms of growth rate, while coconut agar demonstrated the most biomass production regardless of $\mathrm{pH}$.

Study limitations and implications: The growth of cultures in vitro is slow when compared with other mushrooms species. Findings/Conclusions: Floccularia luteovirens cultivation represents an alternative to obtain food with a high nutritional value, safeguard germplasm, and increase and diversify species cultivated; since it is edible, with high nutritional content and has medicinal properties.
\end{abstract}

Key words: strain, biomass, in vitro culture, golden mushroom, culture mediums

\section{INTRODUCTION}

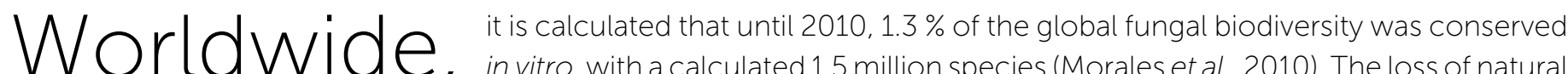

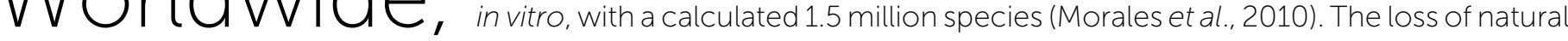
habitats has had an unfavorable impact on the population of wild species, and therefore fungal culture collections acquire a more significant relevance for in situ conservation (Salmones and Mata, 2012).

In Mexico, different collections safeguard 1639 strains of edible species for their study and cultivation, and include local organisms as well as from other countries (Salmones and Mata, 2012).

Despite this great genetic potential, the number of strains safeguarded does not have a positive correlation with the number of species that are currently cultivated on a commercial or
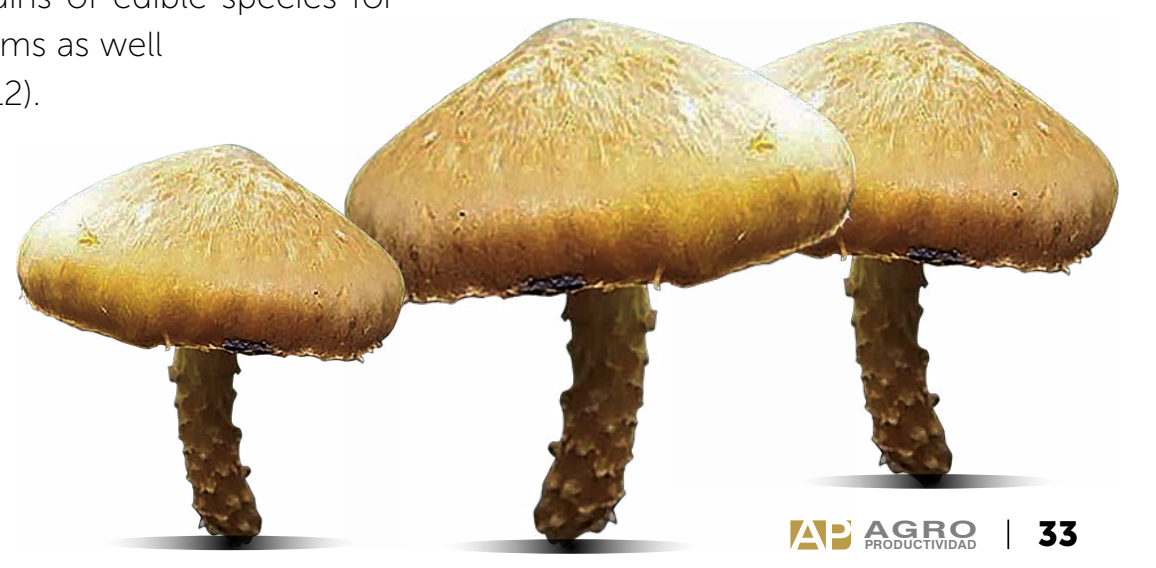
industrial level, and experimentation on new species is scarce. Unlike Asian countries where more than 20 species are cultivated commercially, or the USA and Canada with supermarket sales of numerous cultivated and wild species, the majority sold in Mexico are of Asian origin (Garibay-Orijel et al., 2010). Because of this, using wild mushroom strains represents an alternative in order to take advantage of local genetic resources.

Floccularia luteovirens [whose synonyms are Agaricus luteovirens, Armillaria luteovirens, Floccularia straminea, Tricholoma luteovirens (Fungorum Index, 2019)], is a reported edible mushroom in Asia and Mexico. In Asia it is commonly known as "Golden mushroom", and is valued as an important ecological and medicinal species (Malaisse and Mathieu, 2008). In Mexico, its consumption has been reported in the state of Tamaulipas (Garcia, 2013), Morelos (Avila et al., 1980), Puebla and Estado de México; in the latter, in Amanalco, Zinacantepec, Toluca (Burrola-Aguilar et al., 2012; Franco et al., 2012; AranaGabriel et al., 2014), Chalco, Amecameca, and Ozumba (Estrada et al., 2009). In Estado de México it is commonly known as "hongo de yema", "canario" and "hamburguesa". Davis et al. (2012) report it as a mycorrhizal mushroom, while Evenson (1997) and Garibay Orijel and Ruan Soto (2014) suggest it is saprobic with fructification in coniferous forests, specifically in Abies religiosa and Pinus-Quercus forests (García, 2013; Arana-Gabriel et al., 2014). Floccularia luteovirens is a good source of protein (41.7\%); it contains minerals ( $\mathrm{P}, \mathrm{K}, \mathrm{Ca}, \mathrm{Mg}, \mathrm{Na}, \mathrm{S}, \mathrm{Cl}, \mathrm{Fe}$ $\mathrm{Mn}$ and $\mathrm{Zn}$ ), amino acids (tyrosine, valine, isoleucine, leucine, histidine, lysine, and tryptophan) and acids such as palmitic, stearic, oleic, and linoleic (Malaisse and Mathieu, 2008). Among its medicinal properties it is antioxidant, anticancer and antitumor, due to the presence of gastrodin, exopolysaccharides, betulinic acid, and lectins in the mycelium and in the fruiting body (Hai-Feng et al., 2008; Liu et al., 2011). Cultivation of F. luteovirens is an example of strategies which implicate conservation, research, innovation and the development of genetic resources of native fungi (Morales et al., 2010). Taking into account biotechnological implications, it is important to determine the conditions in which the mycelium develops under in vitro conditions. Therefore, the objective of the present study was to evaluate mycelial growth and biomass production of $F$. luteovirens in different culture mediums and $\mathrm{pH}$ values.

\section{MATERIALS AND METHODS}

The IE 5034 strain of F. luteovirens was used, deposited in the ceparium in INECOL (Institute of Ecology), which was isolated by Arana-Gabriel et al. (2014). For the characterization and evaluation of mycelial growth, five culture mediums were used: 1.- Water Agar (WA) (15 g of Agar-BD Bioxon ${ }^{\text {MR }}$ per liter of distilled water), 2.- Potato Dextrose Agar (PDA) (39 g of PDA-BD Bioxon ${ }^{\mathrm{MR}}$ per liter of distilled water), 3.- Malt Extract Agar (MEA) (33.6 g of MEA-BD Bioxon ${ }^{M R}$ per liter of distilled water), 4.- Corn Meal Agar (CMA) (15 g of MASECA ${ }^{\circledR}$ corn meal, $15 \mathrm{~g}$ agar BD Bioxon ${ }^{M R}, 2$ g BD Bioxon ${ }^{\text {MR }}$ yeast, and $1 \mathrm{~g}$ of peptone per liter of distilled water), 5.- Coconut Water Agar (CWA). A $0.5 \mathrm{~mm}$ diameter piercer was used to place agar with mycelium in the center of each Petri dish, which were incubated in the dark at $18^{\circ} \mathrm{C}$. Each treatment was done with five replicas.

\section{Rate of mycelial growth (Gr) in different culture mediums}

Every third day the diameter of mycelium growth was measured with help of a Vernier scale. Once mycelial growth was completed, Gr was calculated (according to Sinclair and Cantero, 1989):

$$
G r=(D f-D i) /(T f-T i)
$$

Where $G r=$ growth rate; $D f=$ final growth diameter; $D i=$ initial growth diameter; $T f-T i=$ days of mycelial growth.

\section{Biomass (B)}

The mycelium grown in Petri dishes was washed three times with hot water; once the agar was completely eliminated, it was placed on aluminum foil in an oven at $60{ }^{\circ} \mathrm{C}$ for 24 hours, and the dry B was weighed on an analytical scale (Arana-Gabriel et al., 2014).

\section{Morphological and microscopic characterization}

During the exponential growth stage, a sample of mycelium was taken. Preparations were made with 10\% Red Congo. The preparations were observed at a $100 x$ microscope and photographs were taken of the hyphae with the digital Motic microscope DMB3-223 software. At the end of the mycelial growth, the shape, margin, type of growth, texture, surface and color of the colony were registered.

\section{Statistical analysis}

Initially, ANOVA was done (Statgraphics Centurion $X V I$ ), taking into consideration as a factor the type of medium, and $\mathrm{Gr}$ and B as variables. Afterwards, Tukey's test was applied with a cutoff of $p \leq 0.05$ as significant, in order to establish significant differences between 
culture mediums. Once those results were obtained, three mediums were selected whose $\mathrm{pH}$ was modified in order to increase $\mathrm{Gr}$ and B. Subsequently, MANOVA (Statgraphics Centurion XVI) was carried out, with mediums and $\mathrm{pH}$ as factors, and $\mathrm{Gr}$ and $\mathrm{B}$ as variables. Tukey's test was applied with $p \leq 0.05$ as significant in order to establish the difference between culture mediums and $\mathrm{pH}$.

\section{$\mathrm{Gr}$ in different culture mediums at three $\mathrm{pH}$ levels}

The culture mediums CMA, CWA, MEA were adjusted at a $\mathrm{pH}$ of 4.0, 5.0 and 6.0 , by adding $\mathrm{HCl}$ and $\mathrm{KOH}$ 1N (Vázquez-García et al., 2002). With a piercer, 5 $\mathrm{mm}$ diameter of agar with mycelium was taken and placed in Petri dishes (five of each), which were then incubated at $18{ }^{\circ} \mathrm{C}$. Gr was measured, dry B was quantified, and the mycelium was characterized morphologically and microscopically with the methods previously stated.

\section{RESULTS AND DISCUSSION}

Due to the fact that the nutritional requirements of $F$. luteovirens are unknown, PDA and MEA were used as generalized conventional mediums; CMA and CWA as generalized non-conventional mediums, and WA as control. CWA is a culture medium used for in vitro cultivation of plants and there are no reports of it being used for cultivating mushrooms; however

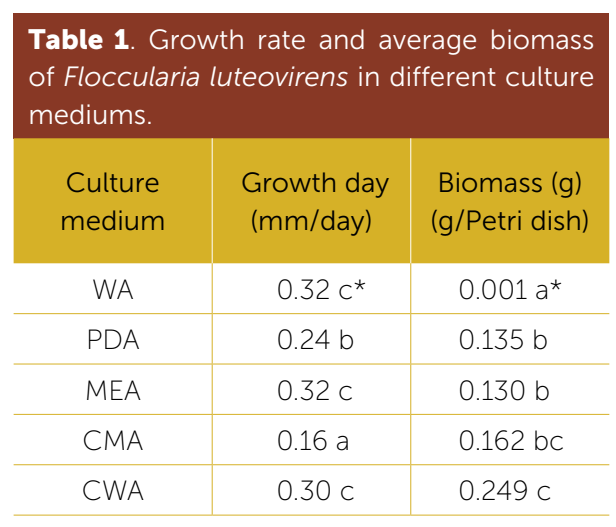

*Different letters in the same column for the same variable indicates significant differences ( $p$ <.05). WA: Water Agar; PDA: Potato Dextrose Agar; MEA: Malt Extract Agar; CMA: Corn Meal Agar; CWA: Coconut Water Agar. in $B(p<0.05)$. The highest $G r$ was seen in the control medium WA with $0.32 \mathrm{~mm}$ day $^{-1}$, invading the complete diameter of the Petri dish in 114 days; then, MEA 0.32 $\mathrm{mm}$ day $^{-1}$ in 111 days, and CWA $0.30 \mathrm{~mm}$ day $^{-1}$ in 123 d; while the CMA showed the slowest $\mathrm{Gr}$ at $0.16 \mathrm{~mm}$ day $^{-1}$ (Table 1). Arana-Gabriel et al. (2014) isolated F. luteovirens in cultures of CMA and MEA, at $18{ }^{\circ} \mathrm{C}$, but they did not evaluate $\mathrm{Gr}$ or $\mathrm{B}$ due to its slow growth. The Gr of F. luteovirens strain is considered slow, when compared to other fungi such as Pleurotus sp. which takes approximately 8-9 days (Gaitán-Hernández, 2005), or other strains of wild mushroom species, such as Flammulina mexicana which takes 13 d, Lyophyllum sp. 21 d (Arana et al., 2014), Suillus luteus 38 d, or Scleroderma citrinum 105 d (González et al., 2015). it was used due to the amount of nutrients reported in the liquid endosperm of the coconut, making it a source of carbon, nitrogen and minerals (Krikorian, 1991), and contributing all the nutritional requirements necessary for good mycelial development. Morphologically, the strain of F. luteovirens in the five different medium cultures presented circular growth, fimbriated edges, submerged growth, velvety texture, flat surface, and a cream color. Microscopically, they presented twisted and branching hyphae, round terminal hyphae, frequent and abundant clamp connection. The diameter of the hyphae varied between culture mediums: in WA the average diameter is $1.84 \mu \mathrm{m}$, in PDA $2.9 \mu \mathrm{m}$, in MEA $3.0 \mu \mathrm{m}$, in CMA 2.5 $\mu \mathrm{m}$, and in CWA $2.6 \mu \mathrm{m}$.

The ANOVA showed significant differences with respect to $\mathrm{Gr}$ in the culture mediums analyzed $(p<0.05)$ and
In terms of $B$, the least amount produced was in the WA culture (without nutrients), and CWA had the most production with $0.249 \mathrm{~g}$ of mycelium. CMA, which had the slowest Gr, produced the most B, only second to CWA (Table 1).

The nutritional contents of each of the cultures analyzed was different, the principal sources of carbon were maltose (MEA), dextrose or glucose (PDA and CWA), sucrose (CWA), fructose (CWA), and starch (CMA). The culture mediums are sources of carbon that the mushroom uses; however, the results in each medium were different, and the medium which showed the best results was CWA, with the fastest $\mathrm{Gr}$ and highest B production. This could be because this culture has a mixture of carbon sources and when compared to the other mediums it contains eight of the ten vitamins needed by basidiomycota (Chang and Miles, 2004); among these, thiamine and biotin are the most important. Thiamine acts as carboxylase and biotin as a coenzyme for the carboxylase in the regulation of carbohydrate metabolism, therefore since these vitamins are present, the mushrooms metabolic rate is increased, reflected in B and Gr.

The CMA medium also contains riboflavin, thiamine and nicotinic acid, although the medium's main source of carbon is from starch, which is a large polymer. The mushroom's metabolism takes longer to absorb it when 
compared to more simple molecules such as sugar, and this explains why it was the second medium with the most B. For the second stage, the MEA, CMA and CWA mediums were chosen and the strain showed the most growth after 30 days of incubation (Figure 1). With the $\mathrm{pH}$ value adjusted to 4, 5 and 6 , there were no morphological changes to the strain, contrary to what was reported by Vázquez-García et al. (2002) where the adjusted pH can modify the hyphae branching pattern for other strains, such as Laccaria bicolor where presented scarce and lax mycelium at a pH of 8.0, and at a pH of 6.0 the colony was more compact and had abundant airy mycelium; or Terfezia olbiensis which presented a lax and weak colony at a pH of 5.0, but presented a denser colony with abundant airy mycelium at a pH of 8.0.

The multivariate analysis of variance (MANOVA) for growth rate showed significant differences related to culture medium $(p<0.05)$ and $\mathrm{pH}(\mathrm{p}<0.05)$, and a significant interaction between the two factors $(p<0.05)$. In terms of $\mathrm{B}$ there was only a difference with the culture medium $(p<0.05)$, while the $\mathrm{pH}$ value variable did not show any difference $(p>0.05)$ nor did the interaction between the two factors ( $p>0.05)$. In Table 2 the results of the Tukey test of the different culture mediums and $\mathrm{pH}$ are shown with respect to $\mathrm{Gr}$ and $\mathrm{B}$.

The MEA medium with a $\mathrm{pH}$ of 4 presented the fastest $\mathrm{Gr}$, and invaded the Petri dish completely by 98 days, while the CMA culture with a $\mathrm{pH}$ of 6 showed the slowest Gr. None of the CMA cultures invaded the Petri dishes completely. Regarding B, the CWA medium with distinct $\mathrm{pH}$ values showed the highest value with an average of $0.23 \mathrm{~g}$, while the CMA medium showed the least B.
In the CWA, the Gr did not change when the $\mathrm{pH}$ value was adjusted. With reference to $B$, this diminished with a pH of 4 (Table 2). In the CMA culture, $\mathrm{Gr}$ increased from $0.16 \mathrm{~mm}$ day $^{-1}$ to $0.245 \mathrm{~mm}$ day $^{-1}$ with a $\mathrm{pH}$ of 4 , and $\mathrm{B}$ decreased in all three $\mathrm{pH}$ values from $0.162 \mathrm{~g}$ to $0.4 \mathrm{~g} \mathrm{Petri} \mathrm{dish}^{-1}$. In the MEA culture, the Gr increased from $0.3 \mathrm{~mm}$ day $^{-1}$ to $0.4 \mathrm{~mm}$ day $^{-1}$ and there were no significant changes in $\mathrm{B}$ with a $\mathrm{pH}$ of 4 ; with a $\mathrm{pH}$ of 5 , there were no significant changes in $\mathrm{Gr}$ and $\mathrm{B}$ was reduced by half, and with a $\mathrm{pH}$ of 6 growth was inhibited (Table 1 and 2).

There are distinct factors which can influence the in vitro behavior of mushrooms, such as culture medium, temperature, and pH (Vázquez-García et al., 2002). Specifically, this last factor can cause significant changes even in the production of secondary metabolites. Some

\begin{tabular}{|c|c|c|c|}
\hline $\begin{array}{l}\text { Culture } \\
\text { medium }\end{array}$ & $\mathrm{pH}$ & $\mathrm{Gd}(\mathrm{mm} / \mathrm{day})$ & $\begin{array}{c}\text { B } \\
\text { (g/Petri dish) }\end{array}$ \\
\hline \multirow{3}{*}{ MEA } & 4 & $0.406 e^{\star}$ & $0.17 b c^{*}$ \\
\hline & 5 & $0.28 d$ & $0.07 a b$ \\
\hline & 6 & $0 \mathrm{a}$ & $0 \mathrm{a}$ \\
\hline \multirow{3}{*}{ CWA } & 4 & $0.286 d$ & $0.21 \mathrm{c}$ \\
\hline & 5 & $0.281 \mathrm{~d}$ & $0.24 c$ \\
\hline & 6 & $0.2916 d$ & $0.25 c$ \\
\hline \multirow{3}{*}{ CMA } & 4 & $0.245 c$ & $0.04 \mathrm{a}$ \\
\hline & 5 & 0.216 b & $0.06 a b$ \\
\hline & 6 & $0.208 \mathrm{~b}$ & $0.05 a b$ \\
\hline
\end{tabular}

*Different letters in the same column for the same variable indicate significant differences ( $p<0.05)$. MEA: Malt Extract Agar; CMA: Corn Meal Agar; CWA: Coconut Water Agar.
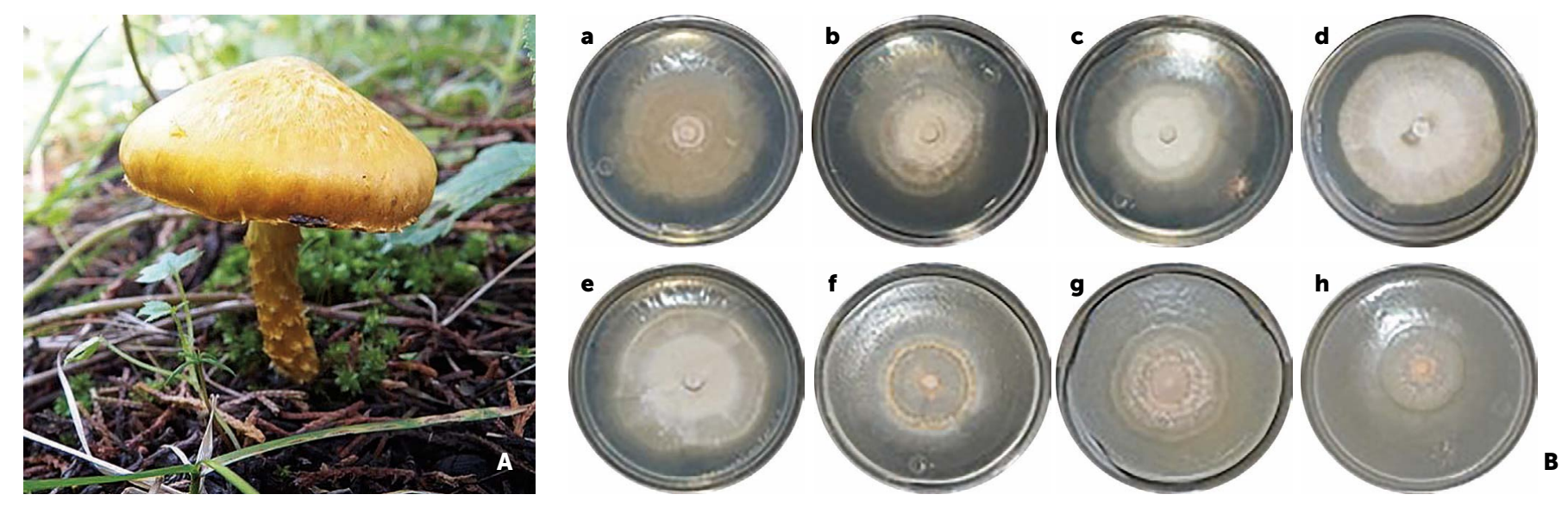

Figure 1. Floccularia luteovirens. A. Sporocarp. B. Strain developing in three culture mediums with three $\mathrm{pH}$ values at $18{ }^{\circ} \mathrm{C}$. a) $\mathrm{MEA}$, $\mathrm{pH} 4$; b) $\mathrm{MEA}$, $\mathrm{pH}$ 5; c) CWA, pH 4; d) CWA, pH 5; e) CWA, pH 6; f) CMA, pH 4. 
species which have reported higher radial growth rates when the $\mathrm{pH}$ value of the culture was modified are Laccaria bicolor (Santiago-Martínez et al., 2003), Suillus luteus, and Scleroderma citrinum (González et al., 2015). Various studies have shown the potential of using native wild mushroom strains, since they have found the right conditions for mass use of strains or for their experimental cultivation (Carreño-Ruiz et al., 2014; Arana-Gabriel et al., 2014; González et al., 2015; Díaz Talamantes et al., 2017). These were done with the goal of offering an alternative for the diversification of cultivated species, conducive to their development in certain environments, and with the resources available in the region of origin of each strain. This is important since these are species valued by the local population, which permits them to take advantage of and appraise their natural resources.

\section{CONCLUSIONS}

The IE 5034 F. luteovirens strain showed an increase in $\mathrm{Gr}$ and $\mathrm{B}$ when $\mathrm{pH}$ value of the culture medium was modified; however a medium that was conducive to the right conditions in order to produce more $B$ in a short period of time was not identified. Even though the strain reached a $\mathrm{Gr}$ of $0.406 \mathrm{~mm}$ per day in the MEA medium with a $\mathrm{pH}$ of 4 , which is higher than that reported in previous studies, it is slow when compared to the development of other mushroom strains, cultivated or wild. In terms of $\mathrm{B}, 0.23 \mathrm{~g}$ Petri dish ${ }^{-1}$ was produced on average in the CWA medium with a $\mathrm{pH}$ of 4,5 and 6. Describing the behavior of wild strains leads to the identification of the nutritional and environmental requirements for the conservation and characterization of native germplasm; as well as knowing the necessary conditions for the optimization of in vitro growth in studies focused on biotechnological aspects, such as the collection of metabolites or experimental cultures where short cycles with high $\mathrm{B}$ are required.

\section{REFERENCES}

Arana-Gabriel, Y., Burrola-Aguilar, C., Garibay-Orijel, R. \& FrancoMaass, S. (2014). Obtención de cepas y producción de inóculo de cinco especies de hongos silvestres comestibles de alta montaña en el centro de México. Revista Chapingo. Serie ciencias forestales y del ambiente, 20(3): 213-226. doi 10.5154/r.rchscfa.2014.04.017

Ávila, B. A., Welden, A. L. \& Guzmán, G. (1980). Notes on the ethnomycology of Hueyapan, Morelos, México. Journal of Ethnopharmacology, 2(4): 311-321. doi: 10.1016/S03788741(80)81013-0

Burrola-Aguilar, C., Montiel, O., Garibay-Orijel, R. \& Zizumbo-Villarreal, L. (2012). Conocimiento tradicional y aprovechamiento de los hongos comestibles silvestres en la región de Amanalco, Estado de México. Revista Mexicana de Micología, 35: 01-16. doi: 10.33885/sf.2012.3.1094

Carreño-Ruiz, S. D., Capello-García, S., Gaitán-Hernández, R., Cifuentes-Blanco, J. \& Rosique-Gil E. (2014). Crecimiento de tres hongos comestibles tropicales en medios de cultivo y residuos agrícolas. Revista Mexicana de Ciencias Agrícolas 5(8): 1447-1458

Chang, S. T. \& Miles P. G. (2004). Mushrooms: Cultivation, Nutritional Value, Medicinal. Effect, Environmental Impact. CRC Press, Boca Raton

Davis, M., Sommer, R. \& Menge, J. (2012). Field guide to mushrooms of western North America (Vol. 106). Univ. of California Press.

Díaz-Talamantes, S., Burrola-Aguilar, C., Aguilar-Miguel, X. \& Mata G. (2017). Crecimiento micelial in vitro de hongos comestibles silvestres de alta montaña en el centro de México. Revista Chapingo Serie Ciencias Forestales y del Ambiente 23(3): 369 383

Estrada, M. E., Guzmán, G., Cibrián, T. D. \& Ortega, P. R. (2009). Contribución al conocimiento etnomicológico de los hongos comestibles silvestres de mercados regionales y comunidades de la sierra nevada (México). Interciencia 34(1): 25-33

Evenson, V. S. (1997). Mushrooms of Colorado and the southern Rocky Mountains. Big Earth Publishing

Franco, M., Burrola C. \& Arana, Y. (2012). Hongos silvestres comestibles: un recurso forestal no maderable del Nevado de Toluca. México: Ediciones Eón/Universidad Autónoma del Estado de México.

Gaitán-Hernández, R. (2005). Evaluación in vitro del hongo comestible Pleurotus eryngii: efecto de diferentes suplementos orgánicos en el crecimiento micelial y producción de cuerpos fructíferos. Revista Mexicana de Micología. 21: 77-84. doi: 10.33885/ sf.2005.3.960

García, J. (2013). Diversidad de macromicetos en el Estado de Tamaulipas, México. Tesis Doctoral, Universidad Autónoma de Nuevo León.

Garibay-Orijel, R., Ruan-Soto, F. \& Estrada-Martínez, E. (2010) El conocimiento micológico tradicional, motor para el aprovechamiento de los hongos comestibles y medicinales. In Martínez-Carrera D., Curvetto N., Sobal M., Morales P. \& Mora V. M. (eds) Hacia un desarrollo sostenible del sistema de producción-consumo de los hongos comestibles y medicinales en Latinoamérica: Avances y perspectivas en el siglo XXI. Red Latinoamericana de Hongos Comestibles y Medicinales-COLPOS-UNS-CONACYT-UAEM-UPAEP-IMINAP, Puebla, pp. 243-270

Garibay-Orijel, R. \& Ruan-Soto, F. (2014). Listado de los hongos silvestres consumidos como alimento tradicional en México. La etnomicología en México: estado del arte. En A. MorenoFuentes \& R. Garibay-Orijel (Eds.). La etnomicología en México. estado del arte. México: CONACYT, UAEH, UNAM

González, M. Quiroz I., Travieso, R., Chung, P. \& García, E. (2015) Determinación de medios de cultivo y pH para la masificación in vitro de cepas de Suillus luteus Aubl. asociadas a Pinus radiata D. Don y Scleroderma citrinum Pers. Asociadas a Eucalyptus globulus Labill. de la región del Biobio, Chile. Revista Árvore, Viçosa-MG, 39(1):105-113. DOl: 10.1590/010067622015000100010 
Hai-Feng, Z., Guo-Qing, H., Jing, L., Hui, R., Qi-He, C., Qiang, Q., Jin-Ling, W. \& Hong-Bo Z. (2008). Production of gastrodin through biotransformation of p-2-hydroxybenzyl alcohol by cultured cells of Armillaria luteovirens Sacc. China. Enzyme and Microbial Technology 43; 25-30. DOI: 10.1016/j.enzmictec.2008.03.007

Index Fungorum (2019). Species Fungorum. Consultado en julio de 2019. http://www.speciesfungorum.org/ Names/SynSpecies.asp?RecordID=330944

Krikorian, A. (1991) Medios de cultivos: generalidades, composición y preparación. In Roca, W. y Mroginski, L. (Ed.), Cultivo de tejidos en la agricultura: Fundamentos y aplicaciones. Cali, Colombia, CIAT. pp. 41-78

Liu, J., Fu, M. L. \& Chen, Q. H. (2011). Biotransformation optimization of betulin into betulinic acid production catalysed by cultured Armillaria luteo-virens Sacc ZJUQH100-6 cells. Journal of applied microbiology, 110(1), 90-97.

Malaisse, F. \& Mathieu, F. (2008). Big bone disease: a multidisciplinary approach of Kashin-Beck disease in Tibet Autonomous Region (PR China). Presses Agronomiques de Gembloux.

Morales, P., Sobal, M., Bonilla, M., Martínez, W., Ramírez-Carrasco, P., Tello, I., Spezzia, T., Lira, N., De Lima, R., Villa, S., Montiel, E., Martínez-Carrera, D. (2010). Los hongos comestibles silvestres en México: recursos genéticos, biotecnología, y desarrollo del sistema de producción-consumo. In MartínezCarrera, D., Curvetto, N., Sobal, M., Morales, P., Mora, V. M. (eds) Hacia un desarrollo sostenible del sistema de producción-consumo de los hongos comestibles y medicinales en Latinoamérica: Avances y perspectivas en el siglo XXI. Red Latinoamericana de Hongos Comestibles y Medicinales-COLPOS-UNSCONACYT-UAEM-UPAEP-IMINAP, Puebla, pp. 91-108.

Salmones, D. \& Mata, G. (2012) Cepario de hongos en México. In Sánchez, V.J. \& Mata, G. (eds) Hongos Comestibles y Medicinales en Iberoamérica, investigación y desarrollo en un entorno multicultural, 1st ed. INECOL-ECOSUR, México, pp. 69-77.

Santiago-Martínez, G., Estrada-Torres, A., Varela, L. \& Herrera T. (2003). Crecimiento en siete medios nutritivos y sintesis in vitro de una cepa de Laccaria bicolor. Agrociencia. 37, 575-584. https://www.colpos.mx/ agrocien/Bimestral/2003/nov-dic/art-3.pdf

Sinclair, C. G. \& Cantero, D. (1989). Fermentation modelling. En: B. McNeil y L.M. Harvey, Fermentation a practical approach. IRL PRESS. Nueva York. pp. 65

Vázquez-García, A., Santiago-Martínez, G. \& Estrada-Torres, A. (2002). Influencia del pH en el crecimiento de quince cepas de hongos ectomicorrizógenos. Anales del Instituto de Biología. UNAM. 73(1), 1-15. http:// www.ejournal.unam.mx/bot/073-01/BOT73101.pdf

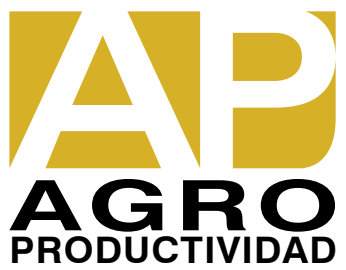

